\title{
リグニンスルホン酸に関する研究 $(\mathbf{V})^{*}$ $\mathrm{SP}$ 排液よりリグニンスルホン酸の分離（その 2 ）
}

\author{
小島義一・林晄・東辻健・舘勇**
}

\author{
Studies on Ligninsulphonic Acid (V) \\ Extraction of Ligninsulphonic Acid with Dicyclohexylamine \\ from Spent Sulphite Liquor (2) \\ Yoshikazu Kojima, Akira Hayashi, Ken Higashitsuji and Isamu Tachi \\ (Department of Agricultural Chemistry, Faculty of Agriculture, University of Kyoto)
}

It was shown, in previous report, that ligninsulphonic acid (LSH) could be extracted with butanol in presence of dicyclohexylamine (DCHA) and sulfuric acid from sulphite spent liquor.

In this report, the role of DCHA in LSH extraction was studied. Acidic groups of ligninsulphonic acid were sulphonic residue, carboxylic residue and phenolic residue. Among these three groups, it was found that phenolic group could not form stable DCHA-salt and other two could form.

Howerer, the only salt of DCHA formed in extraction condition from sulphite spent liquor, was DCHAsulphonate, and the solubility of LSH to butanol came from this DCHA-sulphonate formation.

Moreover, the addition of aromatic amine to LSH was analogous to that of DCHA.

\section{緒 言}

筆者等はこの一連の研究の第 1 報(1) と拈いて, SP 排液から Dicyclohexylamine (DCHA) と硫酸を併用 してブタノール抽出することにより高純度高収量にリ グニンスルホン酸 (LSH) が得られることを報告した。 またその後の報告(2)において DCHA 塩法により抽出 された LSH の分別, 分子量の测定などを行ない, SP 排液中の全 LSH の分布洋来の報告に比し低分子区 分を多く含むことを見出した。

この DCHA 塩抽出法の最適条件の一例を示すと第 1 表の通りである。

\section{Table 1.}

Extraction of LSH with DCHA from SSL

$\mathrm{BuOH}$ : Same Volume to SSL

$\mathrm{H}_{2} \mathrm{SO}_{4}: \mathrm{Eqv} \cdot / \mathrm{CaO}$

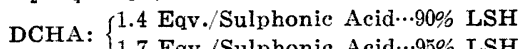
$\mathrm{pH}: 1.5 \sim 2.5$

$\mathrm{LSH}+(<->-)_{2} \mathrm{NH} \rightarrow \mathrm{LSH} \cdot \mathrm{NH}_{2}(-<->>)_{2} \rightarrow \mathrm{BuOH}$ $\mathrm{Ca}\left(\mathrm{HSO}_{3}\right)_{2}+\mathrm{H}_{2} \mathrm{SO}_{4} \rightarrow \mathrm{CaSO}_{4} \underset{\text { ppt. }}{\downarrow}$

即セこの条件下で SP 排液はな踆性であり，90\% 以上の LSHを抽出するには排液中のスルホン基の当 量より過剩の DCHA を必要とする。

この抽出法に批いて, DCHA は LSH 中のスルホン 酸と正規壏を作ってブタノールに溶出したものと推定

\footnotetext{
*原稿受付 35.8 .2

*: 京都大学 農芸化学科㮏颜化学班笢室
}

したが，I.SH 中にはスルホン基以外にもフェノール 基及びカルボキシル基す存在するといわれ(3)，LSH と DCHA の反応梯式については種々の可能性が考觉 られる。更に後述与る如く LSH とアミンの反応には LSH の酸根との正規壏以外にも, 他の結合型式が推 定或いは存在することが示されている。

LSH とアミンの反応としては, 従来から LSH の 定量法として知られている芳香族つミンによる沈測反 応がある。P. Klason(4) とよれば LSH に $\beta$-naphthylamine を作用さすと, 次のような環状塩を形成し水に 不溶性になり沈渴すると述べられている。

$$
\mathrm{C}_{18} \mathrm{H}_{19} \mathrm{O}_{5}-\mathrm{CH}-\mathrm{CH}=\mathrm{NH}-\mathrm{C}_{10} \mathrm{H}_{7}
$$

$$
\mathrm{N}: 3.90 \% \quad \mathrm{~S}: 9.72 \% \quad \mathrm{~N} / \mathrm{S}=0.91
$$

しかし S. V. Hintikka ${ }^{(5)}$ は LSH の芳香族アミン 付加塩はスルホン基の正規塭であると考光た。また内 $\mathbb{⿴ 囗 十}^{(6)}$ は LSH- $\beta$-naphthylamine 塩の沈測現象は主とし て塩析作用に基づくものであり，フミンのスルホン基 に対する付加モ儿数は 0.9 1.10 亿なり, 条件により 必ずしも $1: 1$ にはならないが, スルホン酸の正規塩で あると考えている。また千手(7)によれば LSH と高分 子アミンである polyglycolglucosamine の反応生成物 はアミンのスルホン基に対する比率は $\mathrm{pH}<4$ では 1:1であった。しかし $\mathrm{pH}$ が10を越すとフエノール 基にもアミンが反応すると推定している。

またりグニンをアミンと反応させると，リグニンプ 
ラスチックスが蜘造出来ることが知られており，スル ホン基の有無に関せずアミンが反応することが示され ている(8)。

しかしこのような繥脂慗造の昜合と異なり, 筆者等 の行なった DCHA 塩抽出法の如き温和な反応条件下 では樹脂化の如き反応が起っているとは洘えられず， LSH の酸根注対するアミンの正規塩の生成と考えら れる。このことは LSH-DCHA 塩ブタノール溶液か らのアルカリ抽出結果からも推定出来る所である。

筆者等はこの DCHA 塩抽出法に祘ける LSH のブ タノールヘの溶出効果が DCHA 塩の生成によるもの であることを確かめ, その際の DCHA の挙動を調べ る為汇本実験を行なった。

\section{実験及び考察}

\section{[I] 䟽酸添加の効果}

前報汇抢いて SP 排液に硫酸を添加することにより， 硫酸カルシウムの沈測を生成し分踓がよくなることを 示したが，硫酸の添加により抽出時の排液の $\mathrm{pH}$ は 明らか汇酸性であり, 硫酸の及の添加で DCHA を使 用しなくても若干の LSH が抽出されることが示され ている。硫酸を更に增加した時の効果を調べてみると 第 2 表の通りで岕る。

Table 2. Effect of $\mathrm{H}_{2} \mathrm{SO}_{4} / 50 \mathrm{ml} \mathrm{SSL}$

\begin{tabular}{|cc|}
\hline $\mathrm{H}_{2} \mathrm{SO}_{4}(1: 1) \mathrm{ml}$ & LSA yield $\%$ \\
\hline 0.26 & 4.80 \\
$0.84(\mathrm{a})$ & 15.0 \\
1.00 & 18.9 \\
1.50 & 23.0 \\
5.00 & 33.4 \\
10.00 & 78.5 \\
\hline
\end{tabular}

(a) equivalent to $\mathrm{CaO}$

即ら相当量の硫酸を使用すれば，DCHA を使用し なくても $80 \%$ 程度の LSA がブタノールに抽出され る。しかしこの硫酸酸性の SP 排液からの抽出ブタ,

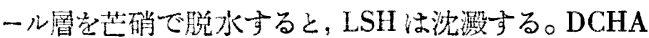
を併用した時にはこのようなことは起らず，LSH と DCHA は化学的に結合してブタノール可溶性を与え ていることは明らかである。

\section{[II] 抽出時における DCHA の挙動}

次江 DCHA 塩法化上る LSH 抽出の際の DCHA の分跑，挙動を謂べる為汇抽出各成分の行方を追求し た。抽出条件は第 1 図の通りである。

即ち $90 \%$ 以上の LSH 艾抽出与る最適条件の一例 と考穴られる抽出条件下で突娩を行なると，加光た DCHA の 86 ? 的ブタノール層化移り，更にその大部
Fig 1

DCHA in S.S.L. Extraction

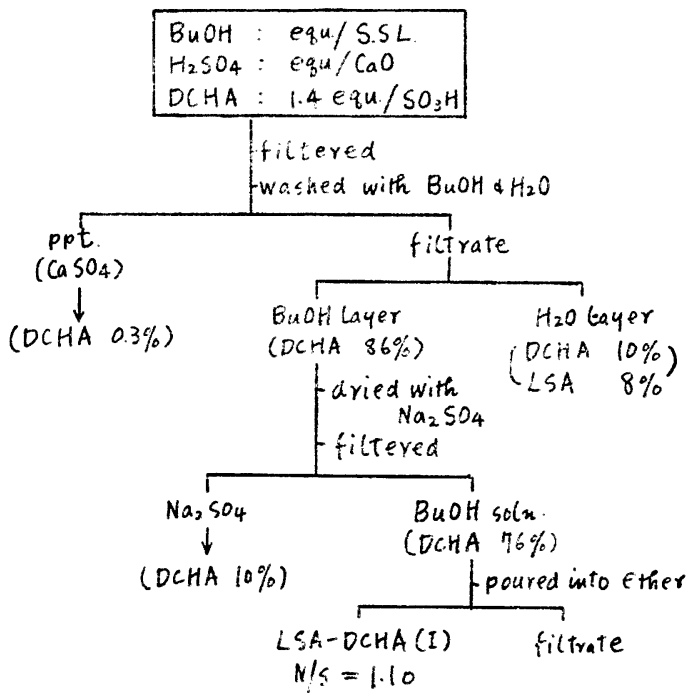

分は脱水しても LSH 上其にブタノール溶液として存 在する。このブタノール滨漁にニーテルを加えて沈激 する LSH (LSH-DCHA I として表示) の分析結果 によると，S: $4.28 \% ， \mathrm{~N}: 2.07 \%$ \%でり，S を全部 スルホン基泊由来すると考完てスルホン基に対する DCHA の付加モル数は 1.10 上なる。即ち DCHA の大 部分は LSH と同一举動定し, 更に得られた LSHDCHA 塩恃性ソーダ抽出を行なうと， N含量はO となりアミンは全部遊離することが判る。このことか らも LSH と DCHA は化学的結合, 多分正規塩を作 っていることが裹付乩机る。

\section{[III LSH の電導度滴定}

LSH は两硫酸蒸劣により尊入されたスルホン基の 他にフェノール基を含み, 更にカルボキシル基の存在 も推定されている。

また LSH 水溶液を強アルカリで電導度滴定すると， 強酸のスルホン基と弱酸のフェノール基が区別定量で きることが知られている。し市しカルボキシル基とフ エノールの分噰定量につ、ては作来確基な方法は知ら れて拈らず，カルボキシル基の量の久なら势先の存否 についても確実なことは判っていない現せである。

前報(2)で報告した分別 LSH 中の1フラクション （VI-6）をカチオン交换澍脂 IR-120 により遊離形と

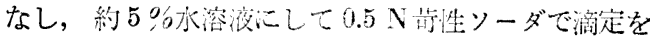
行な5と第 2 図点線の如くになる。同時儿同一条件下

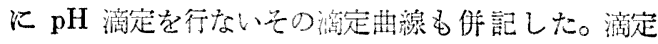
は炭酸ガスの影劉索除くため坴素ガス中で行なった。 一方 DCHA 塩法に上る抽持時の LSH と DCHA 
Fig. 2

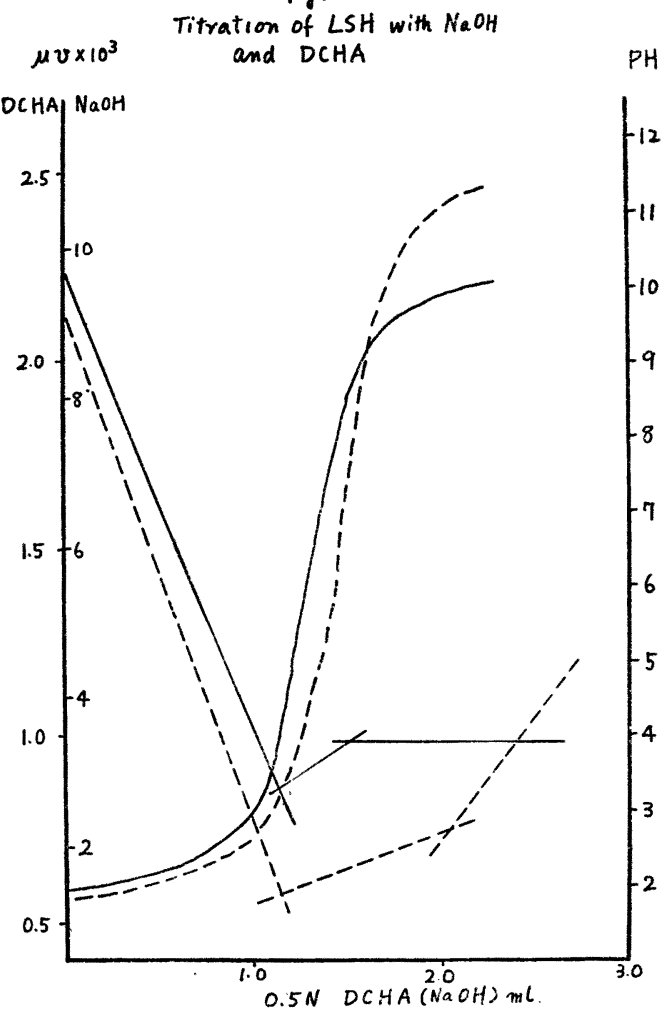

の関係を調べるために，LSH の DCHA に上る滴定 曲線を画くと第 2 図実線の如くになる。LSH-DCHA 塩は水に殆んど不溶でめり, 実除の抽诎時には水飽和 ブタノール中での反応になっている。この滴定実験で は LSH 及び DCHA 共 $80 \%$ メタノール溶液として 滴定を行なった。

第 2 図から判る通り, 強酸の滴定曲線として現われ るスルホン基量は苛性ソーダ, DCHA 共, 同じに測定 されるが，弱酸部は DCHA 滴定の方が苛性ソーダの 場合より遙かに少なくでる。DCHA は弱塩基であり， 解離度の少ないフェノールの如き弱酸を完全汇滴定す ることは出来ず特にスルホン基, カルボキシル基等が 共存する時には，既に生成したこれ等禹酸の DCHA
塩の加水分解作用の為に，フェノールヘの DCHA の 付加は事実上起り得ないことが推定される。従って苛 性ソーダの場合に比べ少ない DCHA 滴定の弱酸基の 中和線は, カルボキシル基或い梳れれ相当する強さ をもつ弱酸の中和であり, 通常の $\mathrm{pKa}=10$ 程度のフ エノール基を含まないことが推定される。この関係の 詳緦については次報扎いて検討する。

\section{[IV] LSH と DCHA の結合割合}

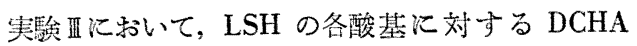
の結合状態を滴定曲線より吟味したが，その状態が穾 際弾離した LSH-DCHA 塩に括いても同㥞である かぞうかを確かめる為に以下の実駼を行なった。

精製 LSH（VI-6） $0.8 \mathrm{~g}$ を $10 \mathrm{ml}$ の水に溶解し， $1.1 \mathrm{~mol} / \mathrm{SO}_{3} \mathrm{H}$ の DCHA を加党 $15 \mathrm{ml}$ のブタノール を加觉て抽出する。ブタノール層を脱水後覞拌しなが ら過剩のエーテル中に注ぎ, LSH-DCHA 塩を沈激さ せ, 沈澱は再びメタノールに溶解後エーテル中で沈淑 さす。この操作を 3 度繰返し乾燥後元素分析すると第 3 表II の如くである（この試料をLSH-DCHA II そす る)。即ち DCHA はスルホン基に対して 1.04 モル結 合している。

次に前実験の電導度滴定図に基づき， $80 \%$ ×タノー ル中で DCHA をスルホン基の中和の終了する $\mathrm{pH}=$ 4.25 迄, 弱酸の中和の終了する $\mathrm{pH}=9.0$ 迄, 更に滈 剩の $\mathrm{pH}=10.0$ 迄加之, そのま減圧下に濃縮乾固後 メタノールに溶かしエーテル中で沈澱精製する。この 操作を 2 回繰返し試料 III, $\mathrm{IV}, \mathrm{V}$ 得る。分析結果は

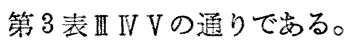

この結果スルホン基化当量の DCHA を加えた杰は， 精製しても N/S 即ちアミン/スルホン基は $1.01 て ゙ ，$ スルホン酸 DCHA 塩が生成しこれは安定であること が判る。一方カルボキシル基を主体とする弱酸基の中 和を完了する $\mathrm{pH}=9.0$ 迄 DCHA を加觉たN（スルホ ン基にに対し $1.33 \mathrm{~mol}$ の DCHA）では, 精舫後アミ ン/スルホン基は1.08にしかならない。なた更に過剩 の DCHA（スルホン基に対し $2 \mathrm{~mol}$ ）索加党たVでは
Table 3. N/S Ratio in LSA-DCHA Preparation

\begin{tabular}{|c|c|c|c|c|c|}
\hline Sample No. & Amine & Preparating Method & $\mathrm{N}$ content & S content & $\mathrm{N} / \mathrm{S}$ \\
\hline$I$ & DCHA & Exted. from SSL & 2.07 & 4.28 & 1.10 \\
\hline II & DCHA & Reexted. LSA & 1.97 & 4.44 & 1.04 \\
\hline III & DCHA & Neutralized to $\mathrm{pH} 4.2$ & 2.08 & 4.86 & 1.01 \\
\hline $\mathrm{N}$ & DCHA & $\begin{array}{ll}\prime \prime & 9.0\end{array}$ & 2.20 & 4.78 & 1.08 \\
\hline $\mathrm{V}$ & DCHA & $\begin{array}{ll}\prime \prime & 10.0\end{array}$ & 2.55 & 4.52 & 1.57 \\
\hline $\mathrm{V}$ & $\beta-\mathbf{N} \cdot A$ & Reacted in $80 \%$ MeOH & 2.30 & 4.40 & 1.19 \\
\hline $\mathrm{V}-\mathrm{a}$ & $\beta-N \cdot A$. & Heated on water bath & 1.89 & 4.72 & 0.93 \\
\hline $\mathrm{V}-\mathrm{b}$ & B-N.A. & Heated with excess $\beta-N$.A. & 2.11 & 4.65 & 0.99 \\
\hline VII & Aniline & Reacted in $80 \% \mathrm{MeOH}$ & 2.37 & 4.97 & 1.09 \\
\hline VII-a & Aniline & Heated on water bath & 1.92 & 5.12 & 0.84 \\
\hline $\mathrm{VII}-\mathrm{b}$ & Aniline & Heated with excess Aniline & 2.03 & 5.04 & 0.85 \\
\hline
\end{tabular}

アミン/スルホン基が 1.27 となり（更に精製を絽返す ともっと減少したものと考 えられる), 何礼もカルボキ シル基定中和した時の 1.33 の值に達しない。フェノー ル基飞 DCHA が付加しな いことは前の電導度滴定図 からも明らかであるが，カ ルボキシル基を主体とする 
弱酸には，滴定曲線からは DCHA 塩が出来る筈である

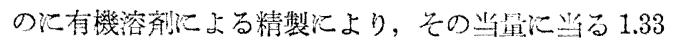
より低い值になる原因は炭酸ガスの影響で心ると考兄 られる。即ら水中での炭酸の第 1 段の解離は $\mathrm{pKa} \fallingdotseq 6.3$ であり，カルボン酸の $\mathrm{pKa} \fallingdotseq 5.0$ に近いが， DCHA で 滴定される弱酸中には炭酸よりも弱い酸基が含まれて いることは十分蒋えられる。従って精製中特に減王淟 縮の際にキャピラリーから吹込音机る空気中の炭酸ガ スにより，遊﨎 DCHA，及び宸酸と同等或いはそれ より弱い酸と塩を生成していた DHCA は DCHA$\mathrm{H}_{2} \mathrm{CO}_{3}$ 墔となり, これはメタノール, エーテルにも 一部可溶であり溶解して除かれる。更に試料の乾燥は 真空下で行なうが，DCHA- $\mathrm{H}_{2} \mathrm{CO}_{3}$ 塩は非常に昇華性 であり，この陵にも昇華により除かれると考えられる。 このことは有機溶凨中の精留及び真空デシケーター 中での乾燥により得られな試料 $\mathrm{N}, \mathrm{V} を, 80 \%$ メタノ 一ル中で再び DCHA で㵜定してみると, 弱酸部分迄 完全に中和して岕ったにもかかわらず，第 3 図化示す 如く精製後には DCHA で中和される弱䐋基が一部再 生していることからる示される。

Fig. 3

\section{Titration of $\angle S A-D C H A \mathbb{V}+\nabla$}

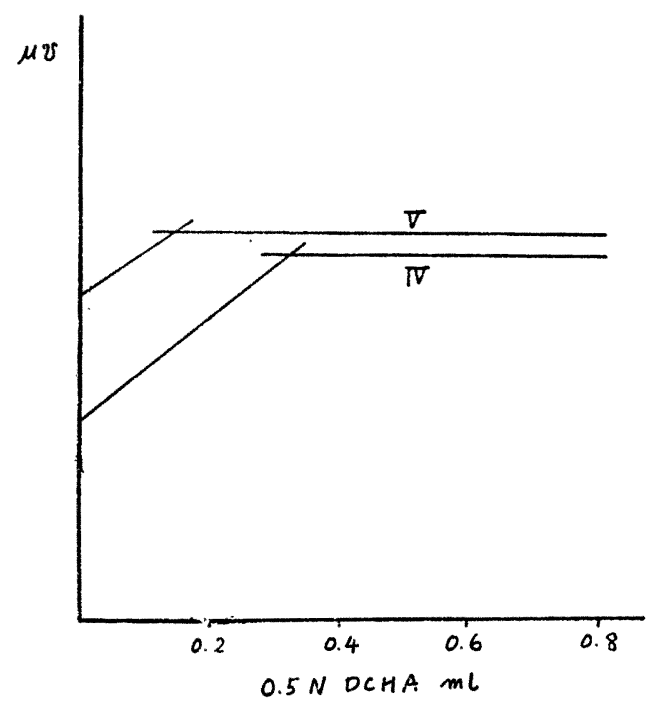

このように DCHA は, LSH のスルホン基，カル ボキシル基々は正規塩を作るがフェノール基は作らず, この関係を利用して電導度滴定を行なえばカルボキシ ル基の定量の可能性が洘光られ，それについては次報 で報告する。またカルボキシル基を中心とする弱酸の DCHA 塩は, 空父中の炭酸ガスの影響の為に一部外 れる可能性が殅ることが判った。
一方 $\mathrm{pH}=2$ 前後で行なわれる DCHA 塩抽出法に よるLSH の抽出の際沈，カルボキシル基の DCHA 塩生成は不可能々考兄られ，スルホン酸塩のみが主体 と考党られる。

\section{[V] 芳香族アミンの LSH への付加}

以上の奏験から，LSH 汇対する DCHA の付加は スルホン基に対する DCHA 塩の生成, 及びカルボキ シル基を主体とする通常のフェノールよりも強い弱酸 飞対する塩の生成よりなりたち，フェノール基には結 合しないことが判った。

前述の通り, SP 排液中のの LSH 定量法として $\beta$ naphthylamine 等の芳香族アミン付加物を作り，关の 沈澱量から LSH の量を訫算する力法が以前より行わ れているが，卡の際に括ける付加形式についてもこれ

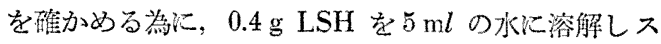
ルホン基の 2.5 当量の $\beta$-ナフチルアミン, 及びアニり ンを $25 \mathrm{~m} l$ メタノールに溶解後加完, 一夜放置後隇压 乾固し，メタノールに溶解後エーテル中で 2 度精製し 試料 VI, UII作った。次江 LSH の定量法汇近い条件 として，VI， VII一部をとり含水メタノールにとかし ウォーターバス上で 1 時間加熱(試料 VI-a, VII-a), 更 に他の一部は含水メタノール過剩の $\beta$-ナフフルフ ン, アニリンを加えて同様に 1 時間加熱する（試料 VI -b, VII-b)。これ等を精製し N.S の分析を行な5と第 3 表の通りである。

尚この際過剩のアミンと共に加熱したVI-b, VII-b は メタノールに不溶であり, 粉砤後アルコール, エーテ ルで洗淮した試料を分析した。

この結果をみると, 芳丕族アミンは DCHA よりも $80 \%$ \%タノール中で更に弱い塩基であるが，LSH に 対する付加は DCHA と同样にスルホン基注刘する塩 が主体であり，一部弱酸にも塩を形成していることが 判る。加熱汇よりアミンの加モル数が減少するのは 矢張り炭酸ガスの影響であると考完られる。加熱後の アミンの付加モル数が 1 よ少さくなるのは芳盾族ア ミンは $\mathrm{pKb} 10$ 程度の弱塩基であり，スルホン基と の塩が一部加水分解され易い為に精製によりアミンの 減少が起ったものと考兑られる。

\section{要約}

実駼が示す如く DCHA 塩抽出法による SP 排腹か らの LSH の抽出は, LSH 中のスルホン基，カルボ キシル基に対する DCHA 塩の形成により,ブタノ一 ル可溶性が生じて抽出が行なわれるものであり, 実際 の抽出条件ではスルホン酸 DCHA 塩が主体である。

(754 面へつづく) 


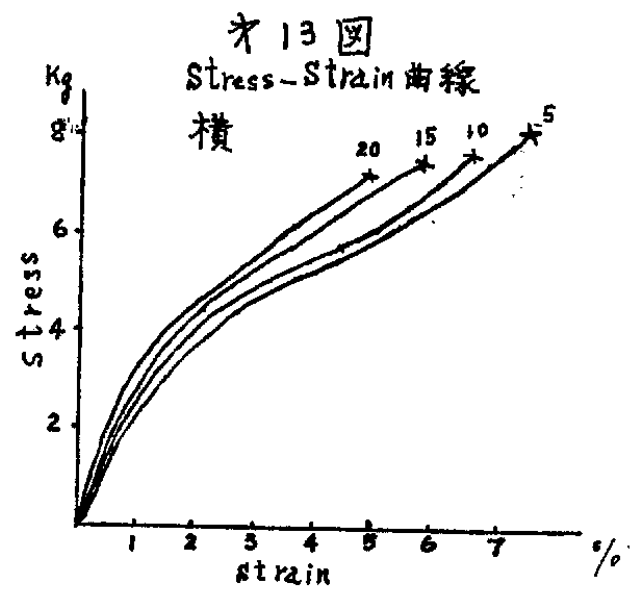

激に低下している。クロス方向についてははっきりし

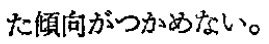

\section{\$4 結 論}

小型の糊貼り袋の破袋訊験を行い, 落下途中の紙の 各種散的強度の变化から, 破㱔と相関のある強度の判 定, 並びに破袋試駼の解析を試みた。 その結果は次のようなるのである。

1）落下回数の増加とともに直線的にしかる大きく減 少する強度が破袋試験と一番相関が高いと考えられ るが，この仮定からみると，縦伸び，横伸びが破袋 との相関が高く，引裂き，破裂ではとれがあまり認
められない。

2）強度試駼では処女紙の强度よりる，をしろ強度の 低下率が重要な意味を持ち，低下率の大きい紙が破 袋までの落下回数が低い。

3）綎と横の長さの違った，いわゆる長方形の袋を落 下させた場合, 長い隹撃エネルギーがより多く 加的る。

4）傾向としていえることであるが，袋の縦方向に絾 のマシン方向をもって来て作ったものが，袋の横汇 紙のマシン方向をもって来て作った袋よりも破袋ま での落下回数が多い。

5） 3） と）から衝整エネルギーの多く加わる方を 艇のマシン方向にするのが望ましいと結馀できる。

6) 袋の直接落下面と，その反対㑡とを比較すると， 反対側に衝慗エネルギーが多く加かる。

7）袋の端と中央部とを比較すると，端にエネルギー が多く加わっている。

\section{文献}

(1) J. Bergstrom, “紙袋の動的条件下での実用的 強度一梳計学的検討一": Svensk Papperstidning $61(1958): 5,119$.

（2） O. Andersson and C. - B. Ihrman, “動的荷重

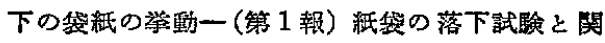
連しての 2, 3 の锶察”: Svensk Papperstidning 62(1959) :9, 303 .

\section{リクニンスルホン酸に関する研究}

(744 佘より)

そしてフェノール基に対する塩の生成は考萝する必要 なく，正規塩以外の付加反応は少なくとも室温下に抽 ける反応では起っていない。

このことは $\beta$-ナフチルアミン，アニリン等の芳查 族アミンの場合も同様であると考えられる。

後記

この研究の费用の一部は文部省科学試滣研究費補助 金を使用した。

\section{引用文献}

（1）舘勇，林睄，小島義一，東辻健：絓，技協誌

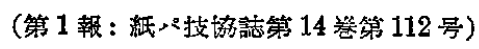

（2）舘勇，中井章能，小島義一：林八技協誌（投稿 中・第 3 報)

(3) J. L. Gardon and S. G. Mason : Can., J. Chem. 331477 (1955)

(4) P. Klason: Ber., 53 706, 1864 (1920)

(5) S. V. Hintikka: Cellulosechem. 493 (1929)

（6）内田潤一：工化 441075 (1941)

(7) 千手䛨-: Bull. Chem. Soc. Japan 25131 (1952), 26143 (1953)

(8) S. I. Aronovsky: Paper Trade J., 113 No. 7 27 (1941) 